\title{
Principal's efforts to change in schools: A case study in Indonesia
}

\author{
Isnaini ${ }^{*}$, Melisa ${ }^{2}$, Rusdinal ${ }^{3}$, Nurhizrah Gistituati ${ }^{4}$ \\ Program Studi Pendidikan Islam Anak Usia Dini, STITNU Sakinah Dharmasraya, Dharmas Raya ${ }^{{ }^{*}}$ \\ Program Studi Pendidikan Matematika, STKIP PGRI Sumatera Barat, Padang ${ }^{2}$ \\ Fakultas Ilmu Pendidikan, Universitas Negeri Padang, Padang ${ }^{3,4}$

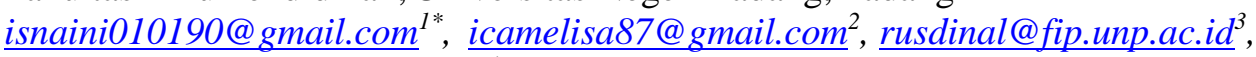
gistituatinurhizrah@gmail.com ${ }^{4}$

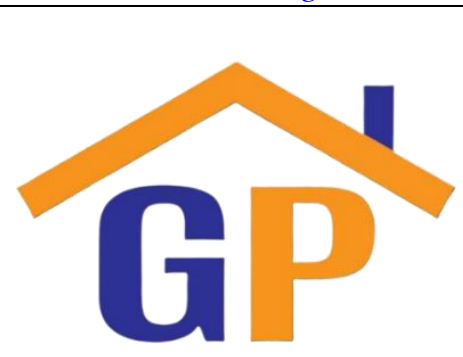

Article History

Received on 8 May 2021

Revised on 15 June 2021

Accepted on 21 June 2021

\begin{abstract}
Purpose: This study aims at describing the principals' efforts to make changes, the factors supporting the changes, and inhibiting factors.
\end{abstract}

Research methodology: This research uses a literature review method to describe the principals' efforts to make changes, the factors supporting the changes, and inhibiting factors.

Results: The results show that (1) the principals' efforts to make changes include catalysts, creators, facilitators, and stabilizers, (2) the supporting factors are the principals' efforts to make changes and support from teachers and parents to make these changes, and (3) there are several factors, including inhibiting factors. These factors are unfolding needs which include economy, social needs, self-esteem, and individuals that requirefinding new work methods, new work groups that cause inconvenience and obscurity to achieve, limiting the individuals' share of information and school organizational resources, and orthodox thinking leading to underdevelopment of knowledge and skills as well as limiting authority, increasing workload, increasing number of rules, and intimidating individual career development.

Limitations: This study only focuses on the principle of making changes, the factors supporting the changes, and inhibiting factors.

Contribution: This research contributes to the principals' efforts to make changes, the factors supporting the changes, and inhibiting factors to achieve school goals and a good leader to manage the school.

Keywords: Principles, Efforts to change, Indonesia

How to cite: Isnaini., Melisa., Rusdinal., \& Nurhizrah Gistituati. (2021). Principal's efforts to change in schools: A case study in Indonesia. Journal of Social, Humanity, and Education, 1(4), 241251.

\section{Introduction}

One of the places to produce quality resources is education. If education can be interrelated with one another, then the goals of development will be well achieved (Kooli C, 2020). Improvement in the quality of education can develop if it lies with the principal, teachers, and all elements involved in the school. Controlling the school requires a school principal who can manage the school properly to achieve school goals. A school must have a good vision, mission, and management and be realized through the principal's efforts (Kooli C, 2019).

To achieve all of that, the principal should work together with the community around the school environment because it can support education that leads to changes both in the social and political fields in society (Kooli, Jumrah, and Al-Abri, 2019). As a leader, the principal is responsible for developing 
teachers in all aspects. Practically, the principal must have good leadership skills to make wise decisions and improve the quality of education. The quality of education in question is the principals' efforts to maximize it properly.

It makes changes all the time. If these changes are carried out properly, they will achieve targets, especially changes in schools. Along with the times and technology demands, changes in schools, such as policies, society, information technology, culture, and many others make school principals able to survive in school quantity and quality (Turan and Bektas, 2013; Nehez and Blossing, 2020). School principals make these changes through a school-based quality improvement management framework. Changes must also be included in the school development plan and the school operational plan, and then implemented, monitored, and evaluated. All changes refer to improving the quality of education (Kooli C, 2017). The difference examines school change and the characteristics of its success, the causes of school failure, and the role of the principal to bring about school changes. The features of school change include (a) school development that can achieve goals, (b) school development that results in learning, (c) school development that obtains resource support, (d) school development that does not hurt the environment around the school, and (e) school development that creates ecological diversity and the capacity of the educational environment and society (Andriani, 2008).

Facilitating Changes in School is the principals' effort to make school improvements. The principals' efforts are aimed at improving the unattainable quality of school education. According to Wibowo (2012), change is a transformation from a current state to a better state that is expected in the future. Change is a life that can encourage someone to change something different from the previous one. These changes involve the role of the principal as a leader in the school, including being able to build effective work relationships, shifting managerial functions, being a leader as a role model, being able to make decisions wisely, influencing others, developing teamwork, involving subordinates in decision making, and building commitment. As for some of the efforts made by the principal, they include (a) making future changes; (b) being the leader as the motor of change; c) clarifying the steps taken in achieving change; (d) balancing change and continuity; and (e) increasing worker satisfaction. Some school programs have not been achieved in Indonesian schools, namely the PAKEM learning training program for teachers. However, teachers in the class cannot entirely implement this because they still adapt the traditional model. Another example of a program that has not been achieved is classroom action research (CAR) to improve quality competencies in their learning (Chang et al., 2017). After this classroom action research training, the teachers were less aware of implementing this classroom action research.

The efforts of the principals in making changes in the school are considerable because the principals have the authority over the schools they supervise. This study aims to describe the efforts of the principals in making changes, their supporting factors, and their inhibiting factors in the action of the principals to make changes. The results of this research are relevant to the research of Hao and Yazdanifard (2015) discussing how effective research could facilitate changes in an organization through improvement and innovation. Their research results show that leadership effectiveness can bring about changes and help increase innovation. Change management is meant by trust, culture, a clear vision, which is facilitated by a change. Sulastri and Rifa'i's (2015) research stated a change leader strategy to make acceleration of change in the future, a leader in the vortex of change, steps to lead change, a balance between change and continuity, and increasing worker satisfaction. Therefore, leadership in this study is needed to achieve predetermined targets (Hao and Yazdanifard, 2015).

The formulation of the problem in this study is how the principal's efforts to make changes in the school include the supporting factors and the experimental factors. This study describes the principal's efforts in making changes in the school, the supporting factors, and the experimental factors. 


\section{Literature review and hypothesis development}

School change can be defined as an effort made by the principal to increase school effectiveness (Lunenberg and Omstein, 2006). One of the changes made by the principal comes from government policy. Government policies are made accordingly to improve the quality of schools. Quality can be defined as the level of excellence of a product, either work or effort. The level of beauty is obtained from product parameters with predetermined standards. Quality standards are contained in the national education standards regulated in Government Regulation Number 19 of 2005. The following are some of the indicators that have been achieved:

1. School development that runs for a long time, not only in implementing work programs, but also in achieving predetermined targets.

2. School development to create school changes through learning.

3. School development on resource supports.

4. School development does not have negative factors on the environment around the school.

5. School development towards various ecological and environmental capacities of education and society.

These indicators were adapted by Uyung (2004) by grouping changes into five stages, namely:

1. Research into the current school conditions and conditions achieved.

2. Creating a strategic vision for the school.

3. Planning a school change strategy.

4. Increased commitment, participation, cooperation, and involvement of support from schools and foundations for environmental change.

5. Stability and integrity against changes.

Based on the five stages of change above, there are some relevant studies related to applying the principals' efforts to make changes. The first stage, research evaluation of the school, is conditioned to reach the school targets, such as in the research of (Zhao, Sobri, and Nurabadi, 2018, which examined the change leadership of school principals in improving the quality of education. The results of their research showed that changes were made through the achievement of the targets obtained. Changes need to be made by environmental needs, so that the community does not abandon them. Therefore, a leader is needed, namely the principal, to realize changes. The principals should have a strategy to achieve changes that affect the quality of education in schools. The research result was achieved by having a philosophical role, a person in charge, a locomotive, a motivator, and a partner. Through change, it can create a school culture, discipline students in school rules, develop teacher careers through training, create learning scenarios, create comfort in the learning process, and run tutoring programs. Then, innovation is realized with support from the leadership, foundations, and facilities and infrastructures. The inhibiting factors for changes found were difficulty and low teacher competence as well as poor image of teachers.

Following Belias and Koustelios (2014), these targets are restricted to developing school culture. It needs to improve school rules, increase selection of teachers through their competencies, develop an evaluation of learning outcomes, implement tutoring programs for UN (National Exam) preparation, and develop student's writing competencies through works proposed. The research result is proven to improve the existing school conditions with the changes that have been made. In the second stage, the school creates a strategic vision for the school. The school strategic vision is obtained from observing current school conditions with estimates of changes in the school environment. It can be seen in the results of Kahar's (2008) study discussing the concept of leadership in organizational change in college libraries. Kahar's research results show that organizational change is carried out by selecting each new employee recruitment based on the required competencies. The work of new employees is evaluated based on a particular team formed by Mackillop (2018). The same thing was stated by those who studied the determinant factors of school organizational change in Madura, East Java, Indonesia. This study aims to determine the main factors that can cause changes. This study was analyzed using structural equation modelling (SEM) with probability sampling techniques and AMOS software. The organizational changes referred to in this research are the conditions faced and carried out by every individual in the organization to achieve organizational goals. This research suggests that leadership 
and political pressures are essential factors that indirectly influence a principal to make changes. Meanwhile, it is directly influenced by educational policies led by regional heads in leading their communities (Rozikin et al., 2021).

The third stage is planning the school strategy or what is called the operational plan. The operational plan is implemented to create guidelines for the change actions that the school takes. These change actions are seen in the results of Utami's (2008) study discussing the influence of leadership in organizational change. Utami's (2008) research results show changes in action, for example, the division of labour by making changes to job descriptions with an organizational design using a simple structure (Shauqy, 2016; By, 2020; Kooli and Abadili, 2021).

Maksumah (2017) researched the Principal's Strategy in Improving the Quality of Foreign Language Education in Schools. This study aimed to describe the strategies used by the principal to improve the quality of the Mandarin language program from year to year. This study used a qualitative method with a case study research design. This method was used to observe the phenomena and symptoms that occurred in society. Researchers acted as an instrument to obtain valid data. The research site was at Nurul Jadid Paiton Probolinggo High School, East Java. The selection of research sites was due to the increasing number of alumni studying in China. Data collection used interview techniques with preparation and interview time, observations known by research objects, and documentation derived from books, magazines, documents, regulations, disciplines, meeting minutes, diary records, and others. Data analysis techniques used the stages of analysis, namely data reduction, data presentation, and conclusion withdrawal. To obtain the validity of research data, it was necessary to extend the research time, increase perseverance in obtaining data and information, and triangulate data for data validity from the field. The results showed the principal's efforts to improve the quality of the Language program. These programs were run through extracurricular activities, bringing native speakers, creating mandarin libraries, holding Mandarin teacher meetings, establishing relationships with Independent Language Institutions, and serving and providing the Mandarin language coaches for other schools. The supporting factors in realizing the principal's efforts are language facilities, learning with native Chinese aid teachers, producing outstanding students, and forming extensive relationships. There are obstacles to improving the principal's quality, namely the lack of Chinese aid teachers, limited funding for Chinese aid teachers, overlapping the schedule of taking the language curricular extracurricular program. The principal can evaluate inhibitory factors through language improvement control.

Schools and foundations need environmental change education (Kooli and Abadli, 2021). The involvement of all elements brings about the changes desired by the school (Aslan, Beycioglu, and Konan, 2008), for example, outreach, training, workshops, discussions, are parts of this stage. The realization of this change in stage four can be seen in Supriyana's (2019) research, especially regarding the university library leadership strategy in facing the development of information technology. Supriyana's (2019) research results show that libraries face four challenges. These four factors are (1) the relationship between the library and the campus community, (2) the use of the library budget, (3) keeping libraries abreast of developments in information technology, and (4) maintaining a balance between digital collections and printed materials and various services in the library. The results of this study can make library leadership effective and improve professional expertise to develop skills. The results of this study are relevant to a research by Werang Loupatty and Tambajong (2020), This researched analyzed the effects of principals' transformational leadership on schools' lives in Indonesia: an empirical study in the elementary school of Merauke district, Papua, Indonesia. Their research aimed to discuss the direct influence of the transformational leadership of school principals and teacher morale in Merauke, Papua, Indonesia. The method used in analysing the data was SPSS 21. The results of their research indicate that transformational leadership has a significant effect on the school climate and teacher morale. It appears to be a valuable finding for the Papuan government to pay attention to different programs to provide training to school principals because it can increase knowledge and skills of transformed leadership. 
In the fifth stage, stability and integrity need to change the community around the school. For example, changes in teacher professional behaviour are enhanced through an incentive system for teachers, so that they show competence as professional teachers.

Referring to Yusuf, (2009), there are several leadership functions in school life as follows:

a. Suggestions are needed for teachers to increase motivation in carrying out their duties.

b. To achieve educational targets, supports are needed in order to carry out responsibilities as a teacher.

c. Comfort is a taste to fulfil a need.

d. The principal must be able to create comfort to relieve anxiety.

e. The principal gets into the centre of attention.

$\mathrm{f}$. This is because the principal must be able to maintain integrity.

g. Fostering enthusiasm for teachers and other school staff in order to achieve school goals.

h. The principal should appreciate teachers and other school staff regarding promotions, facilities, and opportunities to continue educational studies.

\section{Research methodology}

This study uses a literature study to describe the principal's efforts to make school changes, the supporting factors, and the inhibiting factors. This literature study analyzed in this study is about the principals' strategic efforts with supporting and inhibiting factors, for example, collecting several reading sources in the form of books, journals, articles, and other reading materials relevant to this research.

\section{Results and discussions}

At this stage, the application of the efforts made by the principals in making changes, the supporting factors, and the inhibiting factors from the efforts made by the principal in providing changes are discussed (Alvesson and Svensson, 2008; Tran, 2017). The principals' efforts to make changes in schools cannot be separated from the duties and functions of the school principals. In general, the duties of the principals can be divided into three parts, namely material administration, personnel administration, and curriculum administration. Material administration deals with fields related to materials, including school business, finance, building, equipment, and others. Meanwhile, personnel administration deals with the administration of teachers, students, and school employees. Curriculum administration is related to curriculum preparation, curriculum coaching, and curriculum implementation. Efforts in managing this require student competence. The role of the principal is as an education administrator, namely making annual program plans, arranging school organizations, and coordinating in implementing them. The principal as a supervisor can give birth to teachers and employees who are responsible for carrying out their duties. Then, teachers develop teaching methods under the demands of their profession to carry out their respective duties. The principal also acts as a manager to achieve educational goals.

Change management needs to achieve the vision and mission, namely planning, organizing, leadership, and evaluation. According to Dubrin (1990), the four cores of change management are explained as follows:

1) Planning is the first step.

2) Organizing is the principals' responsibility to design the organizational structure and regulate the division of work.

3) Staffing refers to the principals' job to fill vacant positions in the organization.

4) Leadership is the principals' function to coordinate to complete work, so that educational goals are achieved.

5) Actuating is related to the function of the principal to implement actions that have not been achieved in schools.

6) Controlling is an activity to ensure that all things are running, such as monitoring organizational performance. 
Changes are influenced by several factors David, (1994) namely:

1) Technology based on rational logic, economics that utilize human resources in meeting needs, social in public relations, and politics in managing power and strength.

2) Planning, which is the process of achieving goals and setting efforts to achieve them with characteristics including specific, measurable, having particular time, short, standard, realistic, flexible, and acceptable.

3) Decision making to determine alternative ways to solve problems.

4) Budgeting to manage a regular income and expenditure budget.

5) Staffing for fulfilment of human resources.

6) Implementation, which includes three functions, leadership, direction, coordination, controlling, and evaluation (obstacles).

In addition, David (1994) stated that the change management approach could be made through the following five stages:

1) Analyzing circumstances to identify their strengths, weaknesses, threats, opportunities, and advantages.

2) Clarifying the vision and mission for the organization change plan.

3) Performing action in the form of finding a solution to the problem found.

4) Repair.

5) Measures to defend against changes that have been made.

The principal in carrying out his leadership correlates with the changes he has made. The leader becomes a driving force as well as a motivator for all residents in the school environment. Thus, the principal's leadership can take the initiative to stimulate activities to work together to achieve educational goals. The principal must be able to motivate and give enthusiasm and confidence to the school community.

As for some factors that affect the improvement in the quality of education, they include:

1) The education that is achieved must follow the education supervision to provide a status of the educational goals achieved.

2) Knowledge of students. This knowledge varies because of the different characteristics of students' intelligence. It is necessary because it is for improving the quality of education.

3) Knowledge of teachers. Teachers are treated as supervisors in order to improve teaching and learning situations in the classroom. This activity can establish cooperation between teachers and students. Therefore, teacher competence is needed in education.

4) Knowledge of the source of supervision activities. The supporting tools used to carry out supervision activities are the school library, lesson plans, teacher handbooks, etc. All supporting tools are used to improve student learning outcomes.

5) Knowledge of teaching. Knowledge about teaching can be obtained from selecting the appropriate method used during learning.

According to Saputro, (2015), here are the same principals' efforts in making changes. The teacher is an essential aspect of the learning process. Therefore, several things need to be improved to maintain teacher quality, namely (a) increasing teacher discipline in order to prevent school programs from not being implemented, (b) increasing teacher knowledge is needed because teachers is required to not only increase their knowledge, but to also continue to higher education, (c) fostering and improving the quality of teacher knowledge through training, workshops, seminars, and school visits outside the region with new assignments for teachers. (d) Another thing that is needed is to develop teacher competence through changes to the school curriculum. In addition, students are also inseparable from teacher monitoring by actively participating in the learning process, so that no students miss lessons. (e) Teachers should also guide students to get good grades in each desired subject. (f) Giving assignments to students given by the teachers can stimulate students in learning. Then, the teachers provide extracurricular activities to support. (g) School facilities and infrastructure are needed to support the learning process, thus providing convenience in achieving education targets. (h) Collaboration with student guardians cannot be ignored because it can help students succeed in learning. 
Implementation of efforts is made by the principal in making changes. The changes in question are changes to make the changes themselves successful, namely:

1. Catalyst

The principal considers this catalyst to be able to make changes through communication in order to develop the school. To reinforce this change, the principal needs to form school change agents, such as community leaders, education experts, and education practitioners. This opinion is supported by a research (Pebriantika et al., 2020) that discussed leadership in green school practices: a case study of the principal's roles towards reducing global warming risk in Lampung. Their research objective was to examine the research points and conceptual frameworks of leadership that contribute to building sustainable schools. The results of their research indicate that there are factors that support the realization of exemplary and school culture and school facilities related to the principal's effort as a school leader. Cooperation between teachers and parents is expected to maintain student behaviour in the school environment by involving the school community in developing the leadership of the principal. This factor can provide educational services, particularly interest in an excellent physical school to build the environment. The function of school change agents is to strengthen changes made by school principals to implement changes, for example, consulting services for directions, strategies, and school change actions. Another effort needed to create change is to develop a learning curriculum. It is because of a significant part of the learning process. The indicators that need to be owned are: (a) PP and syllabus according to the school curriculum prepared by the teachers, (b) delivery of suitable learning materials by the teachers, (c) adjustment of the materials taught with student characteristics, such as age, background, and student development, (d) connections between students, their environment, and their daily lives, (e) provision of new teaching materials, (f) giving types of student learning in the learning process, (g) development of student competencies and skills, so that students can think critically, and (h) utilization of learning outcomes to develop further learning topics.

2. Creator

The principal, as a creator, aims to develop the vision and strategy he achieves. These visions and strategies aree discussed with school change agents. This is done to create the trust of the school community to carry out these visions and strategies. Efforts are made by the principal by advancing teacher professionalism by improving the quality of teacher skills by providing training in order to develop teacher careers and competencies.

3. Facilitator

The principal as a facilitator aims to provide creative ideas by providing the necessary resources, implementing the use of school residents for changes, evaluating changes made, helping to provide solutions to problems faced, such as innovating by finding new ideas to develop schools to increase quality improvement. Efforts made by school principals are controlling all potential teachers and working together to achieve the targets to be achieved as well as stimulating each teacher to increase his/her effectiveness by finding methods and procedures to create a learning process according to the situations and conditions. All of this cannot be separated from the encouragement and motivation of the elements involved, so that teachers are more creative and innovative in carrying out the learning process in the classroom.

4. Stabilizer

The principal as a stabilizer provides stability to the course of change in schools. Efforts are made to improve the management system for schools that need to be improved. Then, promotion to people who are able to provide school changes is made, so that they can achieve successful changes. The action needed is to monitor the planning of the learning process, such as the implementation of learning, competency achievement indicators, learning objectives, teaching materials, time allocation, learning methods, and so on. In addition, mastering student characteristics is due to realizing the performance of teachers who have adequate knowledge of student characteristics. This is necessary to balance theoretically and practically. Theoretically, 
teachers can increase their knowledge by reading relevant books, such as books related to pedagogy, developmental psychology, and learning psychology. Practically, teachers can make direct and indirect observations of students in the learning process. The next effort is for the principal to monitor the implementation and assessment of the teachers. Evaluation is carried out periodically to the teachers while the assessment includes all learning activities, such as determining relevant programs to student characteristics and competencies and performing assessments that can identify gaps carried out by personal teachers, such as assessment of the appropriateness of the learning methods applied by the teachers during the learning process. In addition to evaluation and assessment, supervision is needed in order to improve the quality of teachers teaching in the classroom by developing teacher quality competencies. Supervision is carried out by the principal who aims to improve the performance of education personnel in order to achieve the targets set by the school.

The opinion of Kompri, (2017) states that the efforts of the principal in improving the quality of education are as follows: (a) an educator is a person who implements and develops the curriculum in schools, (b) teacher competency development, (c) a supervisor in order to create a good teaching and learning process in order to improve the quality of education, (d) an administrator in order to provide opportunities for teachers to develop professional education, training, and continue their education, (e) administrator can manage finances and bribes can increase teacher competence, (f) a supervisor is related to the implementation of supervision, (g) this activity is in the form of a visit to the class to observe the methods used to involve students in the learning process, (h) the results of this supervision can determine the strengths and weaknesses of teachers in providing learning material, (i) a leader is meant to develop teacher competence with a leadership style related to the principal's personality, such as honesty, self-confidence, and responsibility, (j) daring to take risks in making decisions as well as having big spirit, maturity, and role model, $(\mathrm{k})$ a working climate is a condition that can motivate teachers to improve teacher competence and performance by focusing on the principle of hard work, (l) an entrepreneur is related to increasing the competence of teachers to bring about changes, especially in the student learning process;

Based on Kompri's, (2017) research, the principal's efforts to determine the quality of education are relevant to school learning programs. Thus, evaluation in the learning process can also achieve learning objectives.

\section{Supporting factors}

The supporting factors make changes. These factors come from the principal himself, supports from the foundation, and existing facilities and infrastructures. It is relevant to Wibowo's (2012) statement explaining that internal factors and external factors influence changes made by school principals. These internal factors come from the principal as a driving force to provide changes through the mindset possessed by the principal. Meanwhile, external factors come from parents who send their children to public schools with limited funds to pay for their children's schooling. It is inversely proportional to private schools that can compete and increase public interest. Another external factor is the increasingly high competition against other schools and this can be done by making changes through the development of new ideas. Another opinion states that the ones that drive changes are competitive forces, economic forces, political forces, globalization forces, social demographic forces, and ethical strength Utami's (2008).

\section{Inhibiting factors}

The inhibiting factors found by the principal in making changes are: (a) people view of change that requires sufficient maturity through the stages of planning, preparation, and consistency of project management, (b) unclear vision of change strategies, both short and long-term ones. Furthermore, it entails finding new work methods and new work groups that cause inconvenience achieving obscurity, (c) culture of scepticism that is negatively charged towards previous organizations, (d) not being able to adapt to changes by conducting training and skills to adapt to changes, (e) not carrying out two-way communication to prevent overlapping information among employees or teachers, (f) narrow thinking and orthodox thinking leading to lagging knowledge and skills, so that they ignore other aspects, such 
as managerial style and managerial behaviour that are needed in changes, (g) limiting authority, increasing workload and number of rules, and intimidating individual career development, (h) unfulfilled needs, namely economic, social, self-esteem, and individual needs, (i) maintaining a school's existence through competitiveness and attractiveness that is optimized with a participatory approach and a consultative approach, (j) the approaches that are carried out by fostering collaboration with school partnerships and increasing active participation with parents of students, (k) the low quality of human resources including in hospitality, the neglect of teacher welfare, low teacher performance, and ethical and moral crises in the global community that keep up with technological developments. It is caused by teachers who have not met the requirements resulting in disruption of the teaching and learning process. There are several aspects to get external challenges. These aspects are difficulties in applying appropriate methods, difficulties in managing time, teachers prioritizing personal interests rather than school interests, frequent changes of teachers who teach due to factors of marriage and civil servants, (1) the lack of welfare of school principals because their job responsibilities should be supported by complete facilities, so that everything related to schools, teachers, and students should be prioritized.

Sulastri and Rifai's (2019) opinion stated that there were three strategies for the failure of change, namely disruption of social and political structures, matched individual abilities with implementation tasks, and insufficient upper-level management supports in strategy implementation activities.

Based on the principal's efforts to make changes in school, the inhibiting factors, and the supporting factors, it is necessary to know the impacts of all the efforts that the principal has made Mulyasa (2015). The following are some of the resulting impacts:

a. Effectiveness in the educational process can be seen in students' use in the learning and knowledge.

b. Creating strong leadership to manage the educational resources in schools.

c. This leadership is used to achieve the vision and mission, goals, and school programs planned to improve the quality of the school.

d. Managing education personnel to increase school needs because they keep up with developments in science and technology to keep school principal's professional.

e. Quality culture is based on professionalism. It has seven elements related to quality culture. These elements are, for example, quality information, responsibility, rewards and punishments, working together, comfort, justice, and compensation.

f. Teamwork is the intelligence that school residents must have the independence to be able to manage schools, so that the ability to perform well can be achieved because principals have adequate resources.

g. The community is needed in the participation for high responsibility and dedication.

h. Transparency management is a unique feature to increase professionalism to involve school residents around the school.

i. Willingness to change gives birth to something good to maintain the quality of education.

j. Continuous evaluation and improvement to determine the level of ability of residents to improve the education process in schools.

$\mathrm{k}$. Responses are needed to create changes in anticipation of things that are not expected to happen.

1. Accountability is carried out by implementing education in achievement reports by parents and the community.

$\mathrm{m}$. Sustainability can improve the quality of human resources and school assets.

\section{Conclusion}

Based on the results of a review of several journals relevant to this research topic, it can be concluded that the principal's efforts in making changes would undoubtedly lead the school to changes. Some changes affect it, such as the supporting factors of instability and the inhibiting factors. It has four factors of supporting factors. They are (1) The principal's efforts are a catalyst for developing the school communication with community leaders, education experts, and educational practitioners, (2) The efforts of the principal as a creator to create the trust of the school community to carry out the vision 
and strategy to achieve changes, (3) the efforts of the principal as a facilitator through the discovery of innovations and new ideas to develop the school and improve the quality of the school, and (4) the principal's efforts as a stabilizer by enhancing the school management system. However, realizing the changes certainly has obstacles faced by the principal. Some of the inhabiting factors include immature planning, lack of targets in achieving the vision and strategy of changes, sceptical culture, inability to adjust to change, overlapping two-way communication, narrow mindset, and unfulfilled economic needs. In other words, changes tend to be realized, planned, and implemented when the principal can face all of the inhibiting factors found.

\section{Limitations and future research}

All factors in principals' efforts to change in schools are analysed in general. There are other factors which are not included and discussed yet.

\section{References}

Alvesson Math and Stefan Sveningsson. (2008). Changing Orgnanizational Culture. London: Routledge Tylor and Francis Group.

Andriani Esti Dwi. (2008). Peran Kepala Sekolah dalam Upaya Mewujudkan Perubahan Sekolah, Jurnal Manajemen Pendidikan, 2 (4), 52-61.

Aslan, M., Beycioglu, K., \& Konan, N. (2007). The need for organizational innovations in public elementary schools. International Journal of Educational Reform, 16,27-37.

Belias Dimitrios and Kousetilos Athanasios. (2014). The Impact of Leadership and Change Management Strategy on Organizational Culture, European Scientific Journal, 10 (7), 18577431.

By Todnem Rune. (2020). Organizational Change and Leadership: Out of the Quagmire, Journal of Change Management, 20 (1), 1-6.

Chang et al. (2017). Investigating the Major Effect of principals' Change Leadership on School Teachers' Professional Development, IAFOR, 5 (3), 139-154.

David, A Nadler. (1994). Manajemen Perubahan. Bogor: Ghahia Indonesia.

Dubrin, Andrew J. (1990). Manajemen dan Fungsi Manajemen. Bandung: Remaja Rosdakarya.

Hao Jun Moo and Yazdanifard Rashad. (2015). How Effective Leadership Can Facilitate Change in Organizations through Improvement and Innovation, Global Journal of Management and Bussines research: A Administration and Management, 15 (9), 1-7.

Indonesia, P. R. (2006). Peraturan pemerintah Republik Indonesia Nomor 19 tahun 2005 tentang standar nasional pendidikan. Jakarta.

Kahar Irawaty A. (2008). Konsep Kepemimpinan dalam Perubahan Organisasi (Organizational Change) pada Perpustakaan Perguruan Tinggi, Pustaha: Jurnal Studi Perpustakaan dan Informasi, 4 (1), 21-27.

Kin Mei Tai and Kareem Abdull Omar. (2013). Principals' Change Leadership Competencies: A Study in Malaysian High Performing Secondary School. Journal of Education and Practice, 4 (27), 101-116.

Kompri. (2017). “Belajar; Faktor-faktor yang Mempengaruhi. Yogyakarta: Media Akademi

Kooli, C. (2017). Transformation du système éducatif Omanais, quarante ans de formation de capital humain: évolution et performance (Doctoral dissertation, Paris, EHESS).

Kooli, C., Jamrah, A., \& Al-Abri, N. (2019). Learning from Quality Audit in Higher Education Institutions: A Tool for Community Engagement Enhancement. FIIB Business Review, 8(3), 218228.

Kooli, C. (2019). Governing and managing higher education institutions: The quality audit contributions. Evaluation and Program Planning, 77, 101713.

Kooli, C. (2020). The philosophy of education in the Sultanate of Oman: between conservatism and modernism. International Journal of Knowledge and Learning, 13(3), 233-245.

Kooli, C., \& Abadli, R. (2021). Could Education Quality Audit Enhance Human Resources Management Processes of the Higher Education Institutions?. Vision, 09722629211005599

Lunenburg, Fred C. and Ornstein, Allan C. (2004). Educational Administration Concepts and Practices. Fourth Edition. Australia: Thomson Wadsworth. 
Mackillop Eleanor. (2018). Leadership in Organisational Change: A Post Structuralist Research Agenda, Journal Sagepub, 25 (2), 205-222.

Maksumah Maula Nikmatul. (2017). Strategi Kepala Sekolah dalam Meningkatkan Mutu Pendidikan Bahasa Asing di Sekolah. Tesis. Malang: UIN Maulana Malik Ibrahim.

Mulyasa. (2015). Menjadi Guru Profersional Menciptakan Pembelajaran Kreatif dan Menyenangkan. Bandung: PT Remaja Rosdakarya

Nehez Jaana and Blossing Ulf. (2020). Practices in Different school and Principals' Improvement Work, International Journal of Leadership in Education, 1-22.

Pebriantika et al. (2020). Leadership in Green School Practice: A Case Study of The Principal's Roles Toward Reducing Global Warming Risk in Lampung Indonesia, Journal of Physics: Conference 1572, The 9th International Conference on Theoretical and Applied Physics (ICTAp) IOP Publishing.

Rozikin M, Musim Qadir Abd, Pratama Indra Bayu. (2021). The Determinant Factors of School Organization Change in Madura East Java Indonesia, International Journal of Evaluation and Research in Education (IJERE), 10 (1), 308-316.

Saputro Wahyu Trio. (2015). Peran Kepala Sekolah dalam Meningkatkan Pendidikan Agama Islam di SMP Darul Ulum Agung Kedung Kandang Malang. Thesis. Malang: UIN Maulana Malik Ibrahim

Sulastri Ayu and Rifai. (2019). Strategi Pemimpin dalam Pengelolaan Perubahan Organisasi, Jurnal Manajemen Pendidikan Islam, 3 (1), 19-38.

Supriyana. (2019). Strategi Kepemimpinan Perpustakaan Perguruan Tinggi Menghadapi Perkembangan Teknologi Informasi, Jurnal Pustaka Ilmiah, 5 (1), 713-725.

Syauqy Khilal. (2016). Kepemimpinan dalam Perubahan Organisasi Perpustakaan Perguruan Tinggi Jurnal Al Tsaqafa, 13(1), 116-124.

Tran Kim Sang. (2017). Google: A Reflection of Culture, Leader, and Management, International Journal of Corporate Social Responsibility, 2 (10), 1-14.

Turan Selahattin and Bektas Fatih. (2013). The Relationship between School Culture and Leadership Practices, Eurasian Journal of Educational Research, 52 (2013, 155-165.

Utami Sri Setyaningsih. (2007). Pengaruh Kepemimpinan dalam Perubahan Organisasi, Jurnal Ekonomi dan Kewiraushaan, 7 (2)124-129.

Uyung Sulaksana. (2004). Manajemen Perubahan.Yogyakarta: Pustaka Pelajar.

Werang Redan Basilius, Loupatty Martha, Tambajong Hesty. (2016). The Effect of Principals' Transformational Leadership on Schools' Life in Indonesia: An Empirical Study in Elementary Schools of Merauke District Papua Indonesia, International Journal of Research in Social Science, 6 (10), 257-273.

Wibowo. (2012). Budaya Organisasi. Jakarta: PT Raja Grafindo Persada

Yusuf, Amin. (2010). Kepemimpinan dalam Masyarakat. Semarang: Bahan Ajar.

Zahro Mar'atuz Anna, Sobri Yusuf Ahmad, Nurabadi Ahmad. (2018). Kepemimpinan Perubahan Kepala Sekolah dalam Peningkatan Mutu Pendidikan, JAMP: Jurnal Administrasi dan Manajemen Pendidikan, 1 (3), 358-363. 